\title{
PENGGUNAAN ALAT PERMAINAN EDUKATIF (APE) MAZE UNTUK MENINGKATKAN MOTORIK HALUS ANAK USIA 4-5 TAHUN DI TK NEGERI PEMBINA KOTA TASIKMALAYA
}

\author{
Anisa Mar'atu Soleha ${ }^{1}$, Yasbiati ${ }^{2}$, Heri Yusuf Muslihin ${ }^{3}$, \\ ${ }^{1}$ Program Studi PGPAUD UPI Kampus Tasikmalaya \\ ${ }^{2}$ Program Studi PGPAUD UPI Kampus Tasikmalaya \\ ${ }^{3}$ Program Studi PGPAUD UPI Kampus Tasikmalaya
}

Email : anisa.maratus18@gmail.com

(Received: November 2018; Accepted: November 2018; Published: Desember 2018)

\begin{abstract}
This research is motivated by difficulties to improve fine motor, which happened to group A in Kindergarten Negeri Pembina Tasikmalaya City, many children less in fine motor development especially create vertical line, horizontal, curve left/right, tilt and circle so become less irregular. This is because learning is still rarely used $A P E$, Especially on fine motor learning. This reaserch is aimed at improving fine motor of children through the use of APE Maze in group A aged 4-5 years old in Kindergarten Negeri Pembina Tasikmalaya City. Class Action Research (PTK) Conducted in collaboration with a teachers and implemented as many as 3 cycles by using models Kemmis and Mc. Taggart. The subject research is group A Kindergarten Negeri Pembina Tasikmalaya City consisting of 15 people that is 9 male and 6 female and a teacher class A. The object of research is the fine motor ability of children using APE Maze. Data collection techniques using observation and documentation, while data analysis technique use descriptive quantitative and qualitative. Each cycle consists of four stages, namely the planning stage, the implementation stage, the observation stage, and the reflection stage. The result of the research have shown that used APE Maze can improve the fine motoric ability of the children. This is evidenced by the improvement of teacher's planning daily lessons, teacher's ability in the learning process and the teacher's ability to use APE Maze and fine motor sklills of early chilhood of each cycle. Contraints obtained during the study are conditioned children, but researchers have managed to overcome them. The result showed that the use of APE Maze can improved the fine motorskill of children aged 4-5 years old in Kindergarten Negeri Pembina Tasikmalaya City.
\end{abstract}

Keywords: APE Maze, Fine Motor of children, Aged 4-5 years old

\begin{abstract}
ABSTRAK
Penelitian ini dilatarbelakangi adanya kesulitan dalam meningkatkan motorik halus, permasalahan yang terjadi pada kelompok A di TK Negeri Pembina Kota Tasikmalaya, masih banyak anak yang kurang dalam perkembangan motorik halus khususnya dalam membuat garis vertikal, horizontal, lengkung kiri/kanan, miring dan lingkaran sehingga menjadi kurang beraturan. Hal ini disebabkan karena pembelajaran masih jarang menggunakan APE, khususnya pada pembelajaran motorik halus. Tujuan penelitian ini adalah untuk meningkatkan motorik halus anak melalui penggunaan APE Maze pada kelompok A usia 4-5 tahun di TK Negeri Pembina Kota Tasikmalaya. Penelitian Tindakan Kelas (PTK) yang dilakukan bekerja sama dengan guru, dilaksanakan sebanyak 3 siklus menggunakan model Kemmis dan Mc. Taggart. Subjek penelitian adalah anak kelompok A TK Negeri Pembina Kota Tasikmalaya yang terdiri dari 15 orang, yaitu 9 orang laki-laki dan 6 orang perempuan dan guru kelas A. Objek penelitian adalah kemampuan motorik halus anak menggunakan APE Maze. Teknik pengumpulan data menggunakan observasi dan dokumentasi, sedangkan teknik analisis data menggunakan deskriptif kuantitatif dan kualitatif. Setiap siklus terdiri dari empat tahap, yaitu tahap perencanaan, pelaksanaan, observasi, dan refleksi. Hasil penelitian yang telah dilaksanakan menunjukkan bahwa penggunaan APE Maze dapat meningkatkan kemampuan motorik halus anak. Hal ini dibuktikan dengan adanya peningkatan kemampuan guru dalam merencanakan pembelajaran harian, kemampuan guru dalam proses pembelajaran dan kemampuan guru dalam penggunaan APE Maze serta kemampuan motorik halus anak usia dini dari setiap siklusnya. Kendala yang diperoleh selama penelitian adalah mengkondisikan anak, namun peneliti telah berhasil mengatasinya. Hasil penelitian menunjukkan bahwa penggunaan APE Maze dapat meningkatkan motorik halus anak usia 4-5 tahun di TK Negeri Pembina Kota Tasikmalaya.
\end{abstract}

Kata Kunci: APE Maze, Motorik Halus Anak, Usia 4-5 tahun 


\section{PENDAHULUAN}

Dalam Undang-Undang Nomor 20 tahun 2003 tentang Sistem Pendidikan Nasional pasal 1 ayat 1 tercantum bahwa: Pendidikan adalah usaha sadar dan terencana untuk mewujudkan suasana belajar dan proses pembelajaran agar peserta didik secara aktif mengembangkan potensi dirinya untuk memiliki kekuatan spiritual keagamaan, pengendalian diri, kepribadian, akhlak mulia, serta keterampilan yang diperlukan dirinya, masyarakat, bangsa dan negara.

Kemampuan motorik halus merupakan kemampuan yang sangat penting untuk menunjang proses pembelajaran. Sumantri (2005: hlm. 143) menyatakan bahwa pengertian motorik halus adalah mengorganisasikan penggunaan sekelompok otot-otot kecil seperti jari jemari dan tangan yang sering membutuhkan kecermatan dan koordinasi mata dengan tangan, keterampilan yang mencakup pemanfaatan dengan alat-alat untuk bekerja dan objek yang kecil atau pengontrolan terhadap mesin misalnya mengetik dan lain-lain.

Berdasarkan Peraturan Menteri Pendidikan dan Kebudayaan Republik Indonesia Nomor 137 Tahun 2014 tentang Standar Nasional Pendidikan Anak Usia dini yang akan digunakan dalam penelitian ini yaitu dalam mengembangkan kemampuan motorik halus anak usia 4-5 tahun diharapkan anak mampu membuat garis vertikal, horizontal, lengkung kiri/kanan, miring dan lingkaran, selain itu juga anak mampu menjiplak atau meniru bentuk, mengkoordinasi mata dan tangan untuk melakukan gerakan yang rumit, dan mengontrol gerakan tangan yang menggunakan otot halus.

Namun pada umumnya kegiatan yang berkaitan dengan motorik halus bagi anak TK masih relatif kurang, kenyataannya pembelajarannya jarang menggunakan APE (Alat Permainan Edukatif). Khususnya pada pembelajaran motorik halus, yang biasa dilakukan guru sehari-hari adalah penggunaan LKA (Lembar Kerja Anak). Ini menunjukan bahwa kurangnya penggunaan media pembelajaran, sehingga anak tidak termotivasi dan kurang bersemangat ketika belajar atau malah bergurau dengan temannya.

Berdasarkan hasil observasi yang dilakukan terhadap kelas A di TK Negeri Pembina Kota Tasikmalaya, ternyata diidentifikasi masih ada anak yang kurang dalam perkembangan motorik halusnya khususnya dalam kemampuan membuat garis vertikal, horizontal, lengkung kiri/kanan, miring dan lingkaran anak menjadi kurang beraturan, kenyataannya anak membuat coretan tegak yang melenggak-lenggok, lengkung kiri kanan tak beraturan, miring yang tidak berarah dan lingkaran yang penyok ataupun yang tak memiliki ujung.

Permasalahan tersebut diakibatkan dari faktor kurang menariknya penggunaan media pembelajaran dalam mengembangkan keterampilan motorik halus anak. Setiap anak mampu mencapai tahap perkembangan motorik halus yang optimal apabila mendapatkan stimulasi yang tepat. Jika anak kurang mendapat rangsangan maka akan membuat mudah bosan. Semakin anak merasa gembira maka semakin mudah pula ia menyerap pengetahuan. Maka dari itu perlu diadakannya alat permainan edukatif yang menarik. Karena melalui bermain, pengetahuan yang diberikan tidak terkesan dipaksakan tapi juga selain menyenangkan dapat menjadikan ketercapaian perkembangan motorik halus yang maksimal.

Salah satu cara yang dapat digunakan oleh guru adalah penggunaan alat permaianan edukatif Maze yang dibuat dan dihias semenarik mungkin sehingga dapat menstimulasi kemampuan motorik halus anak. APE Maze adalah alat permainan yang terbuat dari papan atau kayu serta memiliki alur berliku dan warna yang berbeda-beda pada setiap alurnya sehingga menjadi alat permainan yang menarik

Berdasarkan latar belakang dan pemaparan diatas, maka peneliti tertarik untuk melakukan perbaikan pembelajaran melalui 
penelitian tindakan kelas dengan judul "Penggunaan Alat Permainan Edukatif (APE) Maze untuk Meningkatkan Motorik Halus Anak Usia 4-5 Tahun di TK Negeri Pembina Kota Tasikmalaya".

\section{TINJAUAN PUSTAKA}

\section{Anak Usia Dini}

Menurut Isjoni (2011, hlm. 24) Anak usia dini adalah individu yang sedang mengalami proses pertumbuhan dn perkembangan yang sangat pesat. Bahkan dikatakan sebagai lompatan perkembangan. Karena itulah anak usia dini dikatakan sebagai golden age (usia emas), yaitu usia yang sangat berharga dibandingkan usia-usia selanjutnya, usia tersebut merupakan fase kehidupan yang unik.

Pendidikan Anak Usia Dini merupakan bentuk penyelenggaraan pendidikan yang menitikberatkan pada peletakkan dasar ke arah pertumbuhan dan perkembangan fisik motorik, kognitif, sosial emosional, bahasa, moral/agama, dan seni. Hal ini sejalan dengan pendapat Pulkkinen (dalam Eeva Hujala, 2002, hlm. 21) "...early childhood education is the keystone of a person's life, growth and learning..." jadi pendidikan anak usia dini adalah batu kunci kehidupan, pertumbuhan, dan pembelajaran seseorang.

Menurut Isjoni (2011, hlm. 25-26) anak usia 4-6 tahun memiliki karakteristik antara lain: Berkaitan dengan perkembangan fisik, anak sangat aktif melakukan kegiatan, Perkembangan bahasa juga semakin baik, perkembangan kognitif sangat pesat, bentuk permainan anak masih bersifat individu bukan permainan sosial.

\section{Kajian Tentang Alat Permainan Edukatif Maze}

Menurut Gerlach dan Ely (Dalam Mukhtar Latif dkk, 2014, hlm. 151) menyatakan bahwa media adalah manusia, materi, atau kejadian yang membangun kondisi yang membuat siswa mampu memperoleh pengetahuan keterampilan, atau sikap. Media yang biasa digunakan di PAUD adalah Alat Permainan Edukatif (APE). Media pembelajaran sangat dianjurkan untuk mempertinggi kualitas pembelajaran.

Media pembelajaran sangat bermanfaat dalam proses pembelajaran. Selain menjadikan hasil belajar siswa lebih bermakna juga membantu guru dalam bahan pengajaran yang lebih menarik dan bervariasi sehingga memberikan kemudahan kepada guru memberikan materi.

Membuat rancangan media menurut Mukhtar Latif, dkk (2014, hlm. 157) sebagai berikut: (1) Menganalisis kebutuhan dan karakteristik siswa, (2) merumuskan tujuan instruksional dengan operasional dan khas, (3) merumuskan butir-butir materi secara terperinci yang mendukung tercapainya tujuan, (4) mengembangkan alat pengukur keberhasilan, (5) membuat desain media, (6) melakukan revisi.

Menurut Yasbiati, dkk (2015, hlm. 1) menyatakan bahwa istilah alat permainan edukatif merupakan suatu hal yang dipandang familiar dalam dunia pendidikan.

Menurut Asni (hlm. 2) Alat Permainan Edukatif Maze adalah alat yang memiliki bentuk-bentuk dengan tujuan agar orang-orang yang memainkan bisa menemukan tempat yang dituju dengan mencari jejak dan dengan menorehkan coretan. Dengan menggunakan APE maze anak bisa melatih otot-otot kecil, seperti keterampilan menggunakan jari-jemari tangan dan pergelangan tangan yang tepat.

Sedangkan menurut Asolihin (dalam Ninda, 2012) menyatakan bahwa maze alur tulis adalah alat permainan edukatif yang terbuat dari kayu yang terdiri dari beberapa alur dan setiap alurnya memiliki warna yang berbeda-beda sehingga dapat menarik perhatian anak

Berdasarkan beberapa pendapat tersebut dapat disimpulkan bahwa Maze adalah alat permainan yang terbuat dari papan atau kayu serta memiliki alur berliku dan warna yang berbeda-beda pada setiap alurnya sehingga menjadi alat permainan yang menarik.

\section{Perkembangan Motorik Halus Anak}


Perkembangan anak usia dini akan menjadi dasar bagi perkembangan selanjutnya. Oleh sebab itu sangat penting dalam mengembangkannya agar tidak terjadi hambatan. Salah satu diantaranya adalah mengembangkan kemampuan motorik halus anak.

Sumantri (2005, hlm. 143) menyatakan bahwa keterampilan motorik halus adalah pengorganisasian penggunaan kelompok otototot kecil seperti jari dan tangan yang sering membutuhkan kecermatan dan koordinasi mata dengan tangan, keterampilan yang mencakup pemanfaatan menggunakan alat-alat untuk mengerjakan suatu objek.

Sehingga dapat disimpulkan bahwa keterampilan motorik halus adalah pengguaan otot-otot halus yang membutuhkan kecermatan dan koordinasi mata dan tangan untuk mengerjakan suatu objek.

Fungsi dan ciri motorik halus adalah keterampilan gerak tangan, gerak jari, mengkoordinasi kecepatan tangan dan mata, melatih penguasaan emosi, serta menjiplak pola sederhana.

Faktor yang mempengaruhi motorik halus anak usia dini salah satunya adalah aktivitas jasmani. Unsur-unsur kesegaran jasmani menurut Bambang Sujiono (2009, hlm. 7.3) diantaranya kekuatan, daya tahan, kecepatan, kelincahan, kelentukan, koordinasi, ketepatan, dan keseimbangan. Salah satu unsur yang termasuk dalam motorik halus diantaranya ketepatan, koordinasi, dan kelenturan.

Ketepatan yaitu kemampuan gerak tubuh seseorang untuk mengendalikan gerak-gerak bebas terhadap suatu sasaran.

Koordinasi (kerapian), koordinasi yang berkaitan dengan mata dan tangan yaitu yang berhubungan dengan kemampuan memilih suatu objek dan mengkoordinasikannya (objek yang dilihat dengan gerakan-gerakan yang diatur) contohnya kerapian dalam membuat garis.

Kelenturan yaitu kualitas yang memungkinkan suatu segmen bergerak semaksimal mungkin menurut kemungkinan rentang geraknya. Fleksibilitas ditentukan oleh kemampuan gerak dari sendi-sendi. Kelenturan sangat dibutuhkan untuk melakukan gerakan.

Pada penelitian ini yaitu menggunakan Alat Permainan Edukatif (APE) yaitu penggunaan APE Maze. APE Maze adalah alat permainan edukatif yang memiliki alur berliku, penggunaan Alat Permainan Edukatif Maze dalam penelitian ini berkaitan dengan permasalahan yang ada di sekolah khususnya dalam kemampuan membuat garis anak yang masih belum optimal, maka dari hal itu yang akan diteliti oleh peneliti melalui penggunaan APE Maze ini adalah untuk meningkatkan motorik halus anak yaitu dalam hal:

a. Menjiplak bentuk terkait menjiplak menggunakan media (APE Maze).

b. Mampu membuat garis vertikal, horizontal, lengkung kiri/kanan, miring dan lingkaran terkait ketepatan mencoretkan garis.

c. Mengkoordinasi mata dan tangan untuk melakukan gerakan yang rumit terkait kerapian atau tepat dalam membuat garis.

d. Mengontrol gerakan tangan yang menggunakan otot halus terkait kelenturan gerakan dalam membuat garis.

Dari kegiatan ini peneliti berharap anak mampu meningkatkan kemampuan motorik halusnya dengan baik.

\section{METODE PENELITIAN}

\section{Desain Penelitian}

Desain Penelitian ini adalah Penelitian tindakan kelas kolaboratif, dalam hal ini peneliti menekankan pada kegiatannya ada keterlibatan pihak lain di luar peneliti. Pihak lain yang dimaksud adalah guru kelas atau guru pamong kelompok A. Jadi, peneliti akan berkolaborasi dengan guru kelas agar tujuan dari penelitian ini dapat tercapai. Tujuan penelitian ini adalah untuk meningkatkan kemampuan motorik halus anak dalam penggunaan alat permainan edukatif Maze pada anak usia 4-5 tahun di TK Negeri Pembina Kota Tasikmalaya. 
Menurut Suharsimi Arikunto, (2013, hlm. 3) penelitian tindakan kelas (PTK) adalah suatu pencermatan terhadap kegiatan belajar berupa sebuah tindakan, yang sengaja dimunculkan dan terjadi dalam sebuah kelas secara bersama. Tindakan tersebut diberikan oleh guru atau dengan arahan dari guru yang dilakukan oleh anak.

Model PTK yang digunakan dalam penelitian ini yaitu model Kemmis \& Mc. Taggart. Model Kemmis \& Mc. Taggart ini terdiri dari empat tahap dalam tiap siklus yaitu perencanaan, pelaksanaan tindakan, observasi dan refleksi. Rancangan penelitian tersebut adalah sebagai berikut:

a. Perencanaan

Perencanaan yaitu peneliti menyusun rencana perumusan masalah, tujuan dan membuat rencana pelaksanaan tindakan kelas termasuk didalamnya instrumen dan perangkat pembelajaran. Pada tahap perencanaan tindakan kelas ini akan dilakukan dengan berbagai kegiatan yang berkaitan dengan rencana pelaksanaan penelitian yang akan diteliti. Peneliti menyiapkan rencana pelaksanaan pembelajaran harian (RPPH), lembar observasi anak, perekam data seperti handphone dan APE Maze untuk meningkatkan kemampuan motorik halus anak.

b. Pelaksanaan

Pelaksanaan yaitu upaya peneliti untuk meningkatkan pemahaman tentang kemampuan motorik halus anak dan mengamati sejauh mana penguasaan guru serta respon anak terhadap tindakan yang diberikan melalui penggunaan APE Maze. Pada tahap ini guru melakukan pembelajaran menggunakan APE maze untuk meningkatkan kemampuan motorik halus anak.

c. Pengamatan

Pada tahap ini peneliti menyiapkan instrumen penelitian untuk guru dan anak. Selama kegiatan berlangsung peneliti mengamati segala proses dalam aktivitas pembelajaran penggunaan APE Maze untuk meningkatkan kemampuan motorik halus anak dengan memberi penilaian berdasarkan instrumen yang ada dilembar pengamatan.

\section{d. Refleksi}

Refleksi merupakan kegiatan memproses data yang didapat saat dilakukan pengamatan. Tahapan refleksi ini dilakukan dengan melihat keseluruhan dari penelitian tindakan kelas yang dilakukan pada siklus I. Dengan adanya refleksi peneliti dapat mengetahui ketercapaian dari mulai perencanaan, pelaksanaan dan pengamatan. Apabila dalam penelitian penggunaan APE Maze untuk meningkatkan kemampuan motorik halus anak belum tercapai maka diulangi kembali dengan melakukan tahapan selanjutnya.

\section{Partisipan dan Tempat Penelitian}

Subjek penelitian dalam penelitian ini adalah siswa (TK) Taman Kanak-Kanak Pembina Kota Tasikmalaya kelompok A (Usia 4-5 Tahun) yang berjumlah 15 orang, yang terdiri dari 9 orang laki-laki dan 6 orang perempuan. Objek penelitian adalah Penggunaan APE Maze untuk meningkatkan kemampuan motorik halus anak usia dini. Pada Penelitian Tindakan Kelas (PTK) kolaboratif ini peneliti dibantu oleh guru pamong yang mengajar dikelas tersebut, yaitu sebagai berikut:

Nama : Ina Nuryani, S.Pd.

Tugas : Observer

Penelitian ini dilaksanakan di Kelompok A TK Negeri Pembina yang berada di Jl. Lingkar

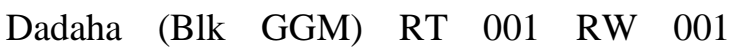
Kelurahan Nagarawangi Kecamatan Cihideng Kota Tasikmalaya. Telah berdiri sejak tahun 2002 dan cukup baik perkembangannya.

\section{Pengumpulan Data}

Jenis data yang digunakan dalam penelitian ini yaitu data Kuantitatif dan data Kualitatif.

Instrumen pengumpulan data dalam penelitian ini yang digunakan adalah lembar observasi. Lembar observasi adalah daftar kegiatan-kegiatan yang mungkin timbul dan akan diamati. Lembar observasi ini untuk mencatat pengamatan yang dilakukan selama 
proses penelitian berlangsung. Instrumen dalam penelitian ini yaitu terdiri dari :

a. Lembar observasi kemampuan guru dalam merencanakan pembelajaran harian (APKG I)

b. Lembar observasi kemampuan guru dalam melaksanakan pembelajaran (APKG II)

c. Lembar observasi kemampuan guru dalam pembelajaran menggunakan Alat Permainan Edukatif (APE) Maze

d. Lembar Observasi kemampuan motorik halus anak

Teknik pengumpulan data yang dilakukan oleh peneliti :

a. Observasi

Menurut Johni Dimyati (2013, hlm. 92) metode observasi merupakan metode pengumpulan data penelitian dengan melalui pengamatan terhadap objek yang diteliti. Teknik ini menggunakan lembar observasi yang didalamnya terdapat butir-butir pernyataan dan pilihan jawaban yang menggambarkan kondisi guru dan siswa saat melaksanakan aktivitas pembelajaran dengan penggunaan Alat Permainan Edukatif (APE) Maze.

b. Dokumentasi

Menurut Johni Dimyati (2013, hlm. 100) metode dokumentasi yaitu teknik pengumpulan data penelitian mengenai hal-hal atau variabel berupa, transkip, buku, surat, koran, majalah, prasasti, notulen rapat, leger nilai, dan lain-lain. Dokumentasi ini dilakukan setiap saat dari observasi kondisi awal, pelaksanaan penelitian, hingga pada saat evaluasi kemampuan motorik halus anak.

\section{Analisis Data}

a. Teknik Analisis Data

Teknik kuantitatif digunakan untuk menentukan peningkatan hasil belajar siswa sebagai pengaruh setiap tindakan yang dilakukan. Sedangkan analisis data kualitatif model Miles dan Huberman (dalam Sugiyono, 2013, hlm. 337-345) mengemukakan aktivitas dalam analisis data, yaitu data reduction, data display, dan conclusion drawing/verification.

b. Indikator keberhasilan
Ukuran keberhasilan belajar ditentukan melalui taraf minimal. Taraf minimal yang ditentukan adalah keberhasilan minimal 75\%. Hal ini Sesuai dengan pendapat Djamarah (2013, hlm. 108) mengemukakan tentang taraf atau tingkat keberhasilan belajar, yaitu sebagai berikut :

1) Apabila $75 \%$ dari jumlah siswa yang mengikuti proses belajar mengajar atau mencapai taraf keberhasilan minimal, optimal, atau bahkan maksimal, maka proses belaar mengajar berikutnya dapat membahas pokok bahasan yang baru.

2) Apabila $75 \%$ atau lebih besar dari jumlah siswa yang mengikuti proses belajar mengajar mencapai taraf keberhasilan kurang (dibawah taraf minimal), maka proses belajar mengajar berikutnya hendaknya bersifat perbaikan (remedial).

Menurut Ngalim Purwanto (dalam Yeni Yuliani, 2017, hlm. 36) Berdasarkan kriteria keberhasilan diatas untuk mengetahui tingkat keberhasilan dari penelitian ini menggunakan rumus penilaian dengan persen. Rumus penilaian dengan persen adalah nilai yang dihitung dalam bentuk persen berdasarkan skor yang diperoleh anak. Cara pemerolehan penilaian dalam persen sebagai berikut:

$$
N P=\frac{R}{S M} \times 100 \%
$$

Keterangan:

$\mathrm{NP}=$ nilai persen yang dicari atau diharapkan

$\mathrm{R}=$ skor mentah yang diperoleh siswa

$\mathrm{SM}=$ skor maksimal ideal dari tes yang bersangkutan

100 = bilangan tetap

c. Prosedur Penelitian

Langkah-langkah prosedur tersebut dilakukan minimal tiga siklus. Berikut prosedur penelitian dilaksanakan seperti prosedur di bawah ini.

1) Orientasi dan Identifikasi Masalah, peneliti mengidentifikasi permasalahan yang ada di TK Negeri Pembina Kota Tasikmalaya.

2) Perencanaan Tindakan, penentuan waktu penelitian, penentuan aspek kemampuan 
motorik halus anak, mempersiapkan instrument, memvalidasi instrument.

3) Pelaksanaan Tindakan Penelitian

a) Tindakan siklus I : perencanaan tindakan pembelajaran, pelaksanaan tindakan pembelajaran, observasi pelaksanaan tindakan, dan refleksi.

b) Tindakan siklus II: perencanaan tindakan pembelajaran, pelaksanaan tindakan pembelajaran, observasi pelaksanaan tindakan, dan refleksi.

c) Tindakan siklus III: perencanaan tindakan pembelajaran, pelaksanaan tindakan pembelajaran, observasi pelaksanaan tindakan, dan refleksi.

d. Isu Etik

Penelitian ini merupakan suatu penanganan permasalahan terhadap kemampuan motorik halus anak. Sehingga pada penelitian ini tidak memiliki dampak negatif terhadap partisipan, baik bagi anak, orang tua, maupun guru di TK Negeri Pembina Kota Tasikmalaya. Dalam penelitian ini identitas dari subjek penelitian dirahasiakan dan hanya ditulis inisialnya saja untuk menjaga privasi partisipan. Peneliti memberikan treatment kepada subjek penelitian yang dipastikan tidak merugikan pihak-pihak yang terlibat serta sesuai kebutuhan yang diperlukan untuk mengatasi permasalahan yang dialami. Treatment yang digunakan peneliti yaitu penggunaan APE Maze, hal ini dilakukan untuk meningkatkan kemampuan motorik halus anak.

\section{HASIL DAN PEMBAHASAN}

Berdasarkan Permasalahan yang telah dirumuskan, tujuan yang ingin dicapai dalam penelitian ini yaitu:

a. Guru mengalami peningkatan kemampuan merancang pembelajaran khususnya dalam kegiatan penggunaan APE Maze untuk meningkatkan kemampuan motorik halus anak yaitu sekurang-kurangnya sudah mencapai $75 \%$.

b. Guru mengalami peningkatan kemampuan dalam mengelola proses pembelajaran khususnya dalam penggunaan APE Maze untuk meningkatkan kemampuan motorik halus anak. Penggunaan media pembelajaran menggunakan APE Maze yang menarik, serta teknik pengenalannya merata kepada seluruh anak secara individu dan sekurang-kurangnya mencapai $75 \%$ dari jumlah indikator yang telah ditetapkan.

c. Anak mengalami peningkatan kemampuan motorik halus melalui penggunaan APE Maze. Keberhasilan tersebut telah mencapai kriteria BSH (Berkembang Sesuai Harapan).

Dan hasil dari tujuan penelitian ini dipaparkan dalam pembahasan sebagai berikut:

\section{Hasil Kemampuan Guru dalam Perencanaan Pembelajaran}

Dari data hasil observasi penilaian Rencana Pelaksanaan Pembelajaran Harian (RPPH) pada siklus I sampai dengan siklus III ternyata dalam kemampuan guru merencanakan pembelajaran harian mengalami peningkatan pada setiap siklusnya. Pada siklus I, jumlah skor yang diperoleh guru dalam merencanakan pembelajaran adalah 11,2 dengan rata-rata 2,8 dan persentase $69,6 \%$ dengan kriteria cukup. Pada siklus II diperoleh peningkatan menjadi 13,16 dengan rata-rata 3,29 dan persentase $82 \%$ dengan kriteria baik. Dan pada siklus III diperoleh peningkatan menjadi 13,5 dengan rata-rata 3,37 dan persentase $85,7 \%$ dengan kriteria sangat baik.

Untuk memperjelas perbandingan peningkatan kemampuan guru dalam melakukan perencanaan pembelajaran harian dari siklus I, siklus II, dan siklus III dapat dilihat pada diagram berikut ini:

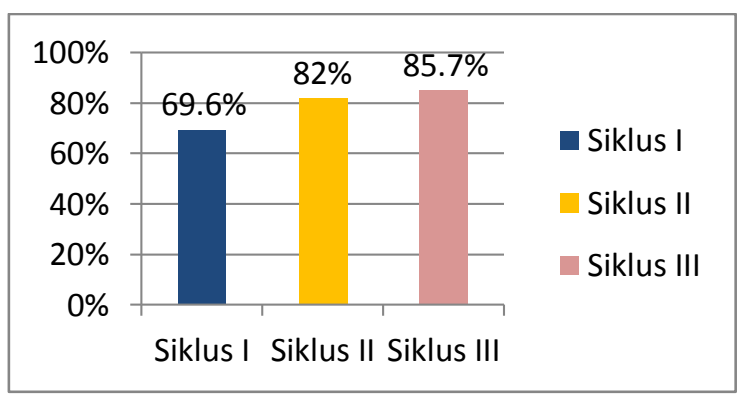


Gambar 4.1

Diagram Peningkatan Pencapaian Perencanaan Pembelajaran Harian (RPPH)

Siklus I, Siklus II, dan Siklus III

\section{Hasil Kemampuan Guru dalam Proses Pembelajaran Menggunakan APE Maze}

Kemampuan guru dalam proses pembelajaran menggunakan APE Maze dapat meningkatkan aktivitas anak dalam pembelajaran. Kemampuan guru dalam proses pembelajaran secara umum, pada siklus I mencapai 8,3 dengan rata-rata 2,7 dan persentase $73,07 \%$ dengan kriteria cukup. Hasil tersebut menunjukan bahwa terdapat beberapa aspek yang masih kurang dan perlu ditingkatkan diantaranya yaitu memeriksa kesiapan siswa, kurang melakukan apersepsi. Oleh karena itu, untuk perbaikan tindakan selanjutnya yaitu sebelum pembelajaran dimulai seharusnya guru terlebih dahulu memeriksa kesiapan siswa dalam mengikuti pembelajaran seperti melakukan tanya jawab, bercakap-cakap ataupu bernyanyi sehingga menarik perhatian anak. Serta sebelum penyampaian materi, guru melakukan apersepsi mengenai kegiatan apa saja yang telah dilakukan anak pada hari sebelumnya. Pada siklus II kekurangan tersebut sudah diperbaiki sehingga mengalami peningkatan menjadi 9,46 dengan rata-rata 3,15 dan persentase $79 \%$ dengan kriteria baik. Meskipun demikian, tentunya masih terdapat beberapa aspek yang harus ditingkatkan yaitu dalam pelaksanaan pembelajaran, belum sesuai dengan alokasi waktu yang telah ditentukan, serta masih menggunakan bahasa lisan yang tidak sesuai dengan EYD. Oleh karena itu perbaikan selanjutnya guru melakukan persiapan yang lebih matang saat melaksanakan pembelajaran dengan memperhatikan alokasi waktu serta menggunakan bahasa lisan yang baik dan benar. Pada siklus III kekurangan tersebut diperbaiki sehingga meningkat menjadi 10,6 dengan rata-rata 3,53 dan persentase $87 \%$ dengan kriteria sangat baik.
Sedangkan pelaksanaan pembelajaran menggunakan APE Maze untuk meningkatkan motorik halus anak di TK Negeri Pembina Kota Tasikmalaya, dari data hasil observasi pada siklus I diperoleh skor 33 dengan persentase $55 \%$ dengan kriteria cukup. Namun masih terdapat beberapa kendala yang masih kurang dan perlu ditingkatkan seperti pada aspek persiapan, guru harus lebih mempersiapkan APE Maze dan pada aspek pelaksanaan dan penilaian guru kurang melibatkan serta kurang memotivasi anak agar mau mengerjakan tugas dengan baik. Kelemahan-kelemahan pada siklus I sudah diperbaiki pada siklus II sehingga hasil observasi penggunaan APE Maze pada siklus II dapat meningkat. Pada siklus II mengalami peningkatan menjadi 45 dengan persentase $75 \%$ dan termasuk kedalam kriteria baik. Meskipun demikian ternyata masih diperoleh kelemahan yaitu guru belum mengkondisikan tempat duduk anak sehingga ada anak yang tidak dapat dibimbing oleh guru pada saat menggunakan Maze, maka dari kelemahankelemahan pada siklus II sudah diperbaiki pada pelaksanaan siklus III, sehingga penggunaan APE Maze dapat meningkat secara optimal menjadi 52 dengan persentase $86,6 \%$ dan termasuk kedalam kriteria sangat baik, ini menunjukan bahwa kemampuan guru dalam pembelajaran menggunakan APE Maze sudah termasuk dalam kriteria keberhasilan yang diinginkan.

Untuk memperjelas perbandingan peningkatan kemampuan guru dalam penggunaan APE Maze dari siklus I, siklus II, dan siklus III dapat dilihat pada diagram berikut:

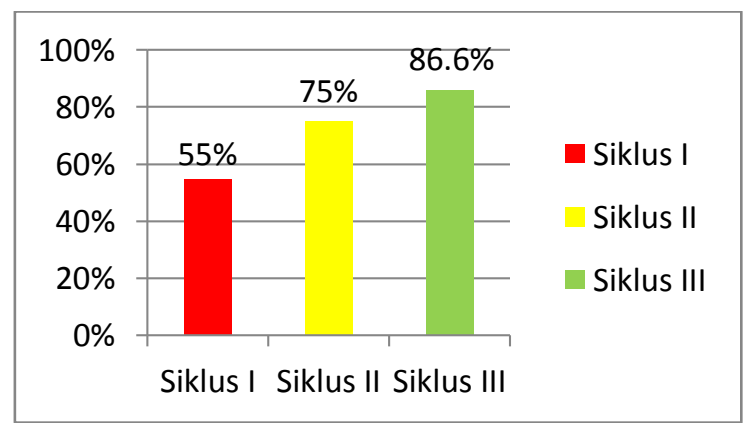

Gambar 4.2 
Diagram Peningkatan Kemampuan Guru dalam Penggunaan APE Maze

Pada Siklus I, Siklus II, dan Siklus III

\section{Hasil Kemampuan Motorik Halus Anak}

Berdasarkan data hasil observasi pada siklus I sampai dengan siklus III menunjukan bahwa kemampuan motorik halus anak melalui penggunaan Alat Permainan Edukatif Maze pada kelompok A (Usia 4-5 tahun) di TK Negeri Pembina Kota Tasikmalaya menunjukkan peningkatan dan perubahan yang lebih baik dari sebelumnya.

Pada siklus I hasil kemampuan motorik halus anak dalam aspek menjiplak menggunakan media hanya 5 orang anak yang termasuk kedalam kriteria Berkembang Sesuai Harapan (BSH), 9 orang anak termasuk kedalam kriteria Mulai Berkembang (MB), dan 1 orang yang termasuk kedalam kriteria Belum Berkembang (BB). Pada aspek ketepatan mencoretkan garis hanya 4 orang anak yang termasuk kedalam kriteria Berkembang Sesuai Harapan (BSH), 9 orang anak termasuk kedalam kriteria Mulai Berkembang (MB), dan 2 orang yang termasuk kedalam kriteria Belum Berkembang (BB). Pada aspek kerapian atau tepat dalam membuat garis hanya 3 orang anak yang termasuk kedalam kriteria Berkembang Sesuai Harapan (BSH), 10 orang anak termasuk kedalam kriteria Mulai Berkembang (MB), dan 2 orang yang termasuk kedalam kriteria Belum Berkembang (BB). Pada aspek kelenturan gerakan dalam membuat garis ternyata terdapat 1 orang anak yang termasuk kedalam krietria Berkembang Sangat Baik (BSB),2 orang anak yang termasuk kedalam kriteria Berkembang Sesuai Harapan (BSH), 10 orang anak termasuk kedalam kriteria Mulai Berkembang (MB), dan 2 orang yang termasuk kedalam kriteria Belum Berkembang (BB). Dari hasil tersebut diperoleh rata-rata kemampuan motorik halus anak sudah termasuk dalam kriteria Mulai Berkembang (MB), hal tersebut belum dikatakan mencapai keberhasilan yang diinginkan karena sebagian besar perkembangan anak belum optimal. Masih terdapat anak yang kesulitan dalam membuat garis karena anak kurang memperhatikan guru sehingga ketika mengerjakan tugas ada yang tidak sesuai dengan apa yang telah dicontohkan. Oleh karena itu guru memotivasi anak untuk lebih baik lagi dengan memberi reward kepada anak seperti stiker bintang dan emoticon jika anak berhasil mengerjakan tugas dengan baik sesuai dengan yang dicontohkan guru. Pemberian motivasi dapat memberikan pengaruh baik bagi anak sehingga anak lebih semangat untuk mengikuti pembelajaran dikelas.

Pada siklus II hasil kemampuan motorik halus anak dalam aspek menjiplak menggunakan media ternyata terdapat 5 orang anak yang termasuk kedalam krietria Berkembang Sangat Baik (BSB), 7 orang anak yang termasuk kedalam kriteria Berkembang Sesuai Harapan (BSH), 3 orang anak termasuk kedalam kriteria Mulai Berkembang (MB). Pada aspek ketepatan mencoretkan garis ternyata terdapat 7 orang anak yang termasuk kedalam krietria Berkembang Sangat Baik (BSB), 6 orang anak yang termasuk kedalam kriteria Berkembang Sesuai Harapan (BSH), 2 orang anak termasuk kedalam kriteria Mulai Berkembang (MB). Pada aspek kerapian atau tepat dalam membuat garis ternyata terdapat 4 orang anak yang termasuk kedalam krietria Berkembang Sangat Baik (BSB), 8 orang anak yang termasuk kedalam kriteria Berkembang Sesuai Harapan (BSH), 3 orang anak termasuk kedalam kriteria Mulai Berkembang (MB). Pada aspek kelenturan gerakan dalam membuat garis ternyata terdapat 5 orang anak yang termasuk kedalam krietria Berkembang Sangat Baik (BSB), 6 orang anak yang termasuk kedalam kriteria Berkembang Sesuai Harapan (BSH), 4 orang anak termasuk kedalam kriteria Mulai Berkembang (MB). Sedangkan untuk kriteria Belum Berkembang (BB) sudah tidak anak yang termasuk kedalam kriteria tersebut. Hal tersebut menunjukan bahwa rata-rata kemampuan motorik halus anak sudah termasuk kedalam kriteria 
Berkembang Sesuai Harapan (BSH). Namun masih terdapat permasalahan yang muncul yaitu masih ada anak yang belum rapi dalam membuat garis dan terkesan terburu-buru serta masih meminta bantuan guru dalam membuat garis. Sehingga dilakukan perbaikan dengan cara guru lebih memotivasi anak dan guru memberi reward kepada anak sehingga anak aktif dan mau mengerjakan tugasnya dengan baik.

Hasil observasi pada siklus III menunjukan bahwa kemampuan motorik halus anak sudah mengalami peningkatan. Terlihat pada aspek menjiplak menggunakan media terdapat 12 orang anak yang termasuk kedalam krietria Berkembang Sangat Baik (BSB) dan 3 orang anak yang termasuk kedalam kriteria Berkembang Sesuai Harapan (BSH). Pada aspek keteapatan mencoretkan garis terdapat 10 orang anak yang termasuk kedalam krietria Berkembang Sangat Baik (BSB) dan 5 orang anak yang termasuk kedalam kriteria Berkembang Sesuai Harapan (BSH). Pada aspek kerapian atau tepat dalam membuat garis terdapat 9 orang anak yang termasuk kedalam krietria Berkembang Sangat Baik (BSB) dan 6 orang anak yang termasuk kedalam kriteria Berkembang Sesuai Harapan (BSH). Pada aspek kelenturan gerakan dalam membuat garis juga terdapat 9 orang anak yang termasuk kedalam krietria Berkembang Sangat Baik (BSB), 6 orang anak yang termasuk kedalam kriteria Berkembang Sesuai Harapan (BSH). Hal tersebut menunjukan bahwa rata-rata kemampuan motorik halus anak sudah termasuk kedalam kriteria Berkembang Sangat Baik (BSB), bahkan sudah ada yang termasuk kedalam kriteria Berkembang Sesuai Harapan (BSH) sehingga sudah mencapai kriteria keberhasilan yang diinginkan.

Untuk memperjelas perbandingan peningkatan kemampuan motorik halus anak pada setiap aspek dari siklus I, siklus II, dan siklus III dapat dilihat pada diagram berikut ini:

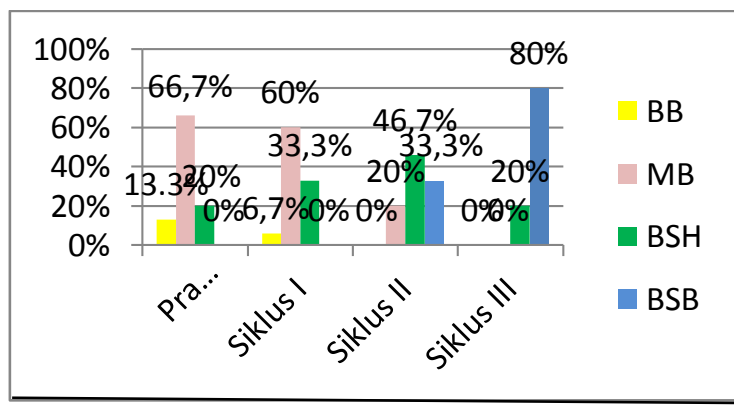

Gambar 4.3

Diagram Perbandingan Aspek Menjiplak Menggunakan Media dari Siklus I Sampai Siklus III

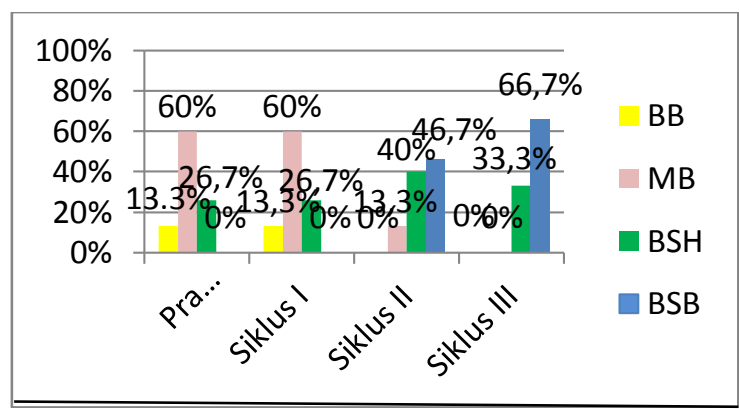

Gambar 4.4

Diagram Perbandingan Aspek Ketepatan Mencoretkan Garis

dari Siklus I Sampai Siklus III

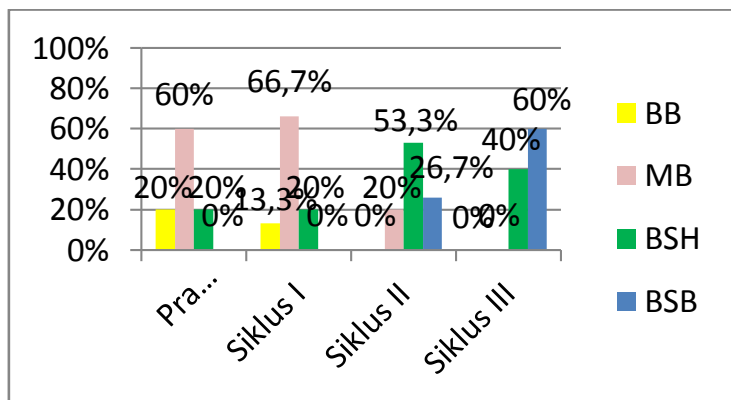

Gambar 4.5

Diagram Perbandingan Aspek Kerapian atau Tepat dalam Membuat Garis dari Siklus I Sampai Siklus III

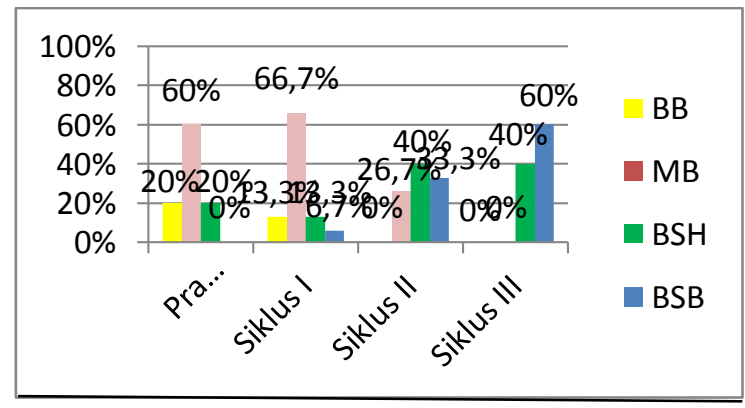

Gambar 4.6

Diagram Perbandingan Aspek Kelenturan Gerakan dalam Membuat Garis 


\section{dari Siklus I Sampai Siklus III}

\section{KESIMPULAN DAN SARAN}

Berdasarkan hasil penelitian tindakan kelas kolaboratif yang telah dilaksanakan dalam tiga siklus yaitu terdiri dari siklus I, siklus II, dan siklus III mengenai penggunaan Alat Permainan Edukatif (APE) Maze untuk meningkatkan kemampuan motorik halus anak usia 4-5 tahun (kelompok A) di TK Negeri Pembina Kota Tasikmalaya, dapat diperoleh kesimpulan sebagai berikut:

1. Kemampuan guru dalam merancang pembelajaran harian (RPPH) melalui penggunaan APE Maze untuk meningkatkan kemampuan motorik halus anak usia 4-5 tahun di TK Negeri Pembina Kota Tasikmalaya, dengan memperhatikan petunjuk penelitian tindakan kelas dan hasil refleksi atau perbaikan dari setiap siklus menunjukkan adanya peningkatan kemampuan guru dalam merancang perencanaan pembelajaran harian (RPPH) melalui penggunaan APE Maze untuk meningkatakan kemampuan motorik halus anak usia 4-5 tahun di TK Negeri Pembina Kota Tasikmalaya.

2. Proses pembelajaran dengan menggunakan Alat Permainan Edukatif (APE) Maze untuk meningkatkan kemampuan motorik halus anak ternyata dapat meningkatkan kemampuan guru dalam kegiatan belajar mengajar untuk meningkatkan kemampuan motorik halus anak usia 4-5 tahun di TK Negeri Pembina Kota Tasikmalaya. Hasil tersebut karena adanya perbaikan atau refleksi dari setiap siklusnya. Penggunaan APE Maze juga menambah wawasan guru dalam memilih media pembelajaran yang tepat untuk diterapkan dan disesuaikan dengan tujuan dari setiap pembelajaran yang diadakan.

3. Kemampuan motorik halus anak usia 4-5 tahun di TK Negeri Pembina Kota Tasikmalaya melalui penggunaan APE
Maze ternyata mengalami peningkatan dari setiap siklusnya.

Berdasarkan hasil penelitian yang telah dilaksanakan, maka implikasi dari penelitian ini adalah sebagai berikut:

1. Melalui penggunaan Alat Permainan Edukatif (APE) Maze dapat meningkatkan kemampuan motorik halus anak, maka kesimpulan tersebut dapat berpengaruh positif pada guru dalam mempertimbangkan proses pembelajaran untuk mencoba menerapkan Alat Permainan Edukatif (APE) Maze untuk digunakan pada pembelajaran selanjutnya.

2. Secara praktis hasil penelitian ini digunakan sebagai bahan masukan bagi guru dan calon guru untuk meningkatkan kualitas siswa melalui penggunaan Alat Permainan Edukatif (APE) Maze dalam proses pembelajaran.

Saran yang dapat diberikan oleh peneliti berdasarkan hasil penelitian mengenai penggunaan APE Maze untuk meningkatkan motorik halus anak yang telah dilakukan adalah sebagai berikut:

1. Rekomendasi untuk guru TK

Guru diharapkan dapat memanfaatkan hasil penelitian ini untuk meningkatkan kemampuan motorik halus anak dengan menggunakan Alat Permianan Edukatif (APE) Maze. Guru diharapkan dapat memilih media yang menarik dalam setiap pembelajaran untuk mengembangakan kemampuan motorik halus anak.

2. Rekomendasi untuk sekolah (Lembaga Pendidikan)

a. Bagi sekolah atau lembaga pendidikan hendaknya menunjang setiap fasilitas pembelajaran agar dalam proses pembelajaran dapat berjalan secara optimal sesuai tujuan yang seharusnya dicapai.

b. Pihak sekolah hendaknya memberikan pelatihan dan memotivasi guru agar lebih kreatif dalam kegiatan pembelajaran, seperti membuat media pembelajaran yang menarik minat anak, menambah rasa 
ingin tahu anak, dan anak senang menggunakan media tersebut, sehingga pembelajaran tercapai dengan baik sesuai tujuan yang seharusnya dicapai

c. Setiap program pembelajaran disusun dan direncanakan dengan matang agar setiap proses pembelajaran berjalan dengan baik dan tepat sesuai tujuan yang akan digunakan.

3. Rekomedasi untuk peneliti selanjutnya Bagi peneliti selanjutnya yang akan melakukan penelitian untuk meningkatakn kemampuan motorik halus anak melalui APE Maze supaya dapat berinovasi dengan melakukan berbagai variasi pembelajaran agar lebih menarik. Sehingga semakin tertarik untuk mengikuti pembelajaran dan kemampuan motorik halus anak semakin meningkat.

\section{DAFTAR PUSTAKA}

Arikunto, S. dkk. (2008). "Penelitian Tindakan Kelas". Jakarta: Bumi Aksara.

Arikunto, Suharsimi. (2013). "Prosedur Penelitian”. Jakarta: RINEKA CIPTA.

Departemen Pendidikan Nasional. (2003). "Undang-Undang Nomor 20 Tahun 2003 tentang Sistem Pendidikan Nasional”. Jakarta: Depdiknas.

Dimyati, J. (2013). "Metodologi Penelitian Pendidikan dan Aplikasi pada Pendidikan Anak Usia Dini”. Jakarta: Prenada Media Group.

Djamarah, Syaiful B, dan Aswan Zain. (2013). "Strategi Belajar Mengajar" Jakarta: PT RINEKA CIPTA.

Febriana, Ninda. (2015). "Pengaruh Penggunaan Alat Permainan Edukatif Maze Alur Tulis Terhadap Keterampilan Motorik Halus Pada Anak Kelompok A TK ABA Janturan Umbulharjo Yogyakarta”. (Skripsi). UNY. Yogyakarta.

Haque, Asni Ariny. __ .Pengaruh Alat Permainan Edukatif (APE) Maze terhadap kemampuan motorik halus pada anak kelompok A Di TK ALFithroh". Surabaya: UNS.
file:///C:/Users/User/Documents/MAZE \%20PDF/jurnal\%20asni.pdf

Hujala, Eeva. (2008). "The Development of Early Childhood Education as an Academic Discipline in Finland Journal". $\quad$ Vol 1, 17-23. file:///C:/Users/User/Documents/journal/ the_development_of_early.pdf.

Isjoni. (2011). "Model Pembelajaran Anak Usia Dini". Bandung: ALFABETA.

Latif, Mukhtar. (2014). "Pendidikan Anak Usia Dini”. Jakarta: PRENADAMEDIA GROUP.

Masnur, Muslich. (2012). "Melaksanakan PTK Itu Mudah”. Jakarta: PT Bumi Aksara.

Nurani S, Yuliani. (2013) . "Konsep Dasar Pendidikan Anak Usia Dini“. Jakarta: PT Indeks.

Peraturan Menteri Pendidikan Dan Kebudayaan Republik Indonesia Nomor 137 Tahun 2014.

Sugiyono. (2013). "Metode Penelitian Pendidikan Pendekatan Kualitatif, Kuantitatif dan R\&D”. Bandung: Alfabeta.

Sujiono, Bambang, dkk. (2009). "Metode Pengembangan Fisik". Jakarta: Universitas Terbuka.

Sumantri. (2005). "Model Pengembangan Keterampilan Motorik Anak Usia Dini". Jakarta: Departemen Pendidikan Nasional Direktorat Jenderal Pendidikan Tinggi Direktorat Pembinaan Pendidikan Tenaga Kependidikan dan Tenaga Perguruan Tinggi.

Yasbiati, Dkk. (2015). "Alat Permainan Edukatif”. Tasikmalaya: Rizki Press.

Yuliani, Yeni. (2017). "Penggunaan Media Papan Flanel Bergambar Untuk Meningkatkan Kemampuan Bercerita Anak Usia Dini Kelompok B TK PGRI Cibeureum Kelurahan Kota Baru Kota Tasikmalaya". (Skripsi). Universitas Pendidikan Indonesia. 